\title{
Claudel's Poetic Conversions
}

\author{
Madhuri Mukherjee \\ William Paterson University of New Jersey
}

Non, Ramakrishna, non Vivekananda et trois fois non, mon vieil ami Romain Rolland, il n'est pas vrai, mais pas du tout vrai, que toutes les religions sont vraies.

-Paul Claudel, Emmaus.

$\mathrm{F}$ rom his first major play, Tête d'Or (1889), to his last great dramatic work, Le Livre de Christophe Colomb (1927), Claudel's theater appears to be structured around what critics have seen as a profound desire for unity of the universe. Claudel's vision of universal unity seems, however, to involve not the harmonious coming together, in symbiosis, of East and West, building upon what they may already have in common. Rather, the poet seeks universality through the conquest of souls, and by the invasion and evangelization of the East by the West. Etymologically, the word "catholic" is derived from the Greek "katholikos," which means "universal," and indeed, Catholicism is the only universality that Claudel appears ready to admit. ${ }^{1}$ Claudel, thus, participates wholly in the Orientalist discourse described by Edward Said in Orientalism. ${ }^{2}$

Not surprisingly, the historical figures that keep recurring in Claudel's writings are those of Western conquerors, explorers, and missionaries, such as Alexander the Great, and Saint Francis-Xavier, who set out Eastward, Christopher Columbus who sought to discover a new route to the East, and Napoleon, who dreamed of conquests in the Orient. Claudel describes Napoleon as: "un romantique échevélé, un homme pourvu par une idée presque mystique qui ne lui laisse pas de repos." $3 \mathrm{He}$ also draws attention to the spirit of adventure of early Christian missionaries: "Dans le côté chrétien, il y a le côté aventure. Il y a, par example, saint François-Xavier qui s'embarque pour la conquête des âmes, qui double le cap de Bonne Espérance, qui va mourir devant les Chinois;" And, referring to Christopher Colombus, Claudel describes his fascination for the explorer: 
Ce personnage [...] me hantait depuis assez longtemps. C'était le héros d'une idée que j'aie toujours eue, cette idée du rassemblement de la terre, de la réunion des différentes parties de l'humanité, et Christophe Colomb me semblait, à ce sujet, un véritable champion et, on peut dire, un saint.

The object of the present essay is to examine the precise manner in which Claudel attempts to realize his particular vision of universal unity through his theater. In the pages that follow, I will analyze the poetic strategy by means of which the poet effects "conversions" to Christianity. Examples from some of his plays, namely, Tête d'Or, Le Repos du septième jour, and Le Livre de Christophe Colomb, will illustrate the specific model of Orientalism practiced by Claudel, and demonstrate how the poet succeeds in realizing, symbolically, his dream of supplanting the non-Christian Orient by a Biblical East.

\section{Tête d'Or}

Tête d'Or provides a strong example of the mechanics of Claudel's Orientalism. Among other issues involved in this complex work, two themes dominate: on the one hand, the psychological and spiritual evolution of the hero, Tête d'Or, and, on the other, the clash between West and East, culminating in the epic-scale battle pitting Tête d'Or's army against the Asian hordes. Analysis of these two themes of the play highlight Claudel's tacit borrowing from Eastern material, and his reworking of what he borrows, in order to fulfill his mission of conversion.

To begin with, episodes in Tête d'Or's life seem to be modeled on the life of the Buddha. For example, in the first part of the play (2nd version), after burying his wife, Simon Agnel ${ }^{4}$ is transformed from an ordinary mortal into a superhuman being, Tête d'Or, destined to be the martial, as well as the spiritual leader of men. This recalls the legend of the Buddha: the Indian prince Siddhartha, who, dissatisfied with his life of ease, convinced there had to be a higher dimension to human existence, leaves his palace, abandoning his wife and child. Siddhartha, meditating beneath the Bodhi tree - the Tree of Knowledge - receives enlightenment after successfully warding off the temptations of Mara, the Evil One, and thus becomes Gautama Buddha, the founder of Buddhism. 


\section{Claudel's Poetic Conversions}

Simon Agnel's transformation, too, takes place under a tree, the «Arbre de Science,» and it happens after he has severed material and emotional ties, leaving his home and family, burying his wife, face down, «la face contre le fond.» Agnel has intentionally sought out the tree, walking many miles, like the Buddha, through the night. Agnel stands below the tree and proclaims: "Mais je veux vous interroger, profondes racines, et ce fonds original de la terre où vous vous nourissez." This is followed by an indeterminate pause, and Agnel's companion, Cébès, senses the transformation of Agnel, understands intuitively that "Quelque loi est mise dans ton coeur, [. . . ] quelque commandement / Et volonté de nonhomme / Te pousse [. . .]" an intuition which Cébès acknowledges by falling to his knees before Tête d'Or, who confirms his own transcendence, exclaiming, "Sache qu'un droit m'a été donné! sache qu'une force m'a été donnée!"

Claudel's description of Agnel transformed into Tête d'Or as «non-homme» is very significant, and reinforces the underlying allusion to the Buddha. Throughout his works, Claudel has repeatedly condemned what he sees as Buddhism's objective, namely, denial of being, the dissolution of self into nothingness. Yet, the poet who has always maintained that «l'être est toujours préférable au non-être,» qualifies Tête d'Or, one of the strongest and most powerful figures in all his dramatic works, not as a superman but as a "non-homme.» Like the Buddha, Tête d'Or appears to have conquered human weakness, overcome human emotion, and become immune to human frailty, as demonstrated later by his unmoved impassivity in the face of Cébès's heart rending agony and death.

Before leaving the scene of the transformation, Tête d'Or and Cébès enact a ritual, which is half baptism by blood, half Holy Communion, in which Cébès is anointed with, and drinks of, the blood of Tête d'Or: "Et voici que j'ai goûté de ton sang, tel le premier vin qui sort du pressoir!" The Tree of Knowledge has now been converted into a Cross: "Et toi maintenant, / Te voici comme une servante qui, avant de partir, / Embrasse l'arbre de la croix." This is a very clear illustration of Claudel's strategy of appropriation, or annexation. In the beginning, was the symbol of the Tree of Knowledge, a symbol central to Buddhism. Claudel tacitly borrows this symbol, and completely appropriates and westernizes it. He achieves this transformation by weaving around the original symbol, a web of Biblically inspired poetry, replete with powerful Western, Christian, ritual and symbolism ("la croix," "cette chose crucifiée," "que mon sang jaillisse," "le premier vin," etc.). The original symbol 
is no longer recognizable as Oriental, it emerges, from its poetic refashioning - converted.

Following this scene, Tête d'Or, like the Buddha, forswears all temptation and casts off his weaker, emotional self, symbolized by the death of Cébès. He then begins his career of conquests as a «jeune consul» (literally what Claudel was, at the time of the play's writing). $\mathrm{He}$ becomes king, and leads his armies Eastward. Arriving at the final frontier, Tête d'Or asks «Quel est ce lieu où nous sommes?» to which the answer is:

Il est appelé «la porte», car c'est la dernière porte.

Voici le seuil qui sur le Nord éternel est ouvert et le côté par où le soleil arrive;

C'est ici le rempart, l'oblique jointure par qui l'Europe est attachée à la Terre de la Terre.

The Maître-des-commandements then tells Tête d'Or:

Tourne-toi vers l'Est saint!

Regarde, ô Roi, et prends, car tout cela est à toi .

Avance-toi donc, ô Roi, et franchissons la plaine immense, Afin que nous gravissions la dernière marche et que de l'Asie Nous conquérions l'énorme Autel!»

A formidable battle ensues, reminiscent of the battle between brother and brother in the great Indian epic, the Mahabharata. The fratricidal nature of the war is echoed in Tête d'Or, although with a slight modification Claudel presents the battle as pitting sister against sister, Europe against Asia, East against West («Certes l'humanité antique était venue audevant de sa soeur»). Eventually, Tête d'Or's army emerges victorious, but at the expense of his life. The manner in which this seemingly invincible hero meets his death, recalls a specific moment in the battle of the Mahabharata, the episode in which divine intervention causes darkness to fall before sunset, enabling the warrior-hero, Arjuna, to circumvent the conventions of warfare and kill a quasi-invincible adversary. Tête d'Or's army is advancing, when all of a sudden, 
Voici qu'une fumée se lève de la terre et une épaisse poussière avec un vent véhément, couvrant l'armée.

[...]

Mais quant elle se fut dissipée, nous vîmes

- Une armée infinie qui s'avançait en face de la nôtre.

Tête d'Or's men are so astonished at the sudden, almost supernatural, materialization of an immense army, that they all flee, leaving their leader to face the pagan multitude alone.

Claudel's text never explicitly states that the war Tête d'Or is waging is a Christian war. However, the strong Christian symbolism suggests that Tête d'Or's battle is a crusade to resuscitate the Biblical East, to wrench it from the forces of Hinduism and Buddhism. At stake, after all, is «l'énorme Autel» (de l'Asie). Moreover, here is the description of the army Tête d'Or was facing:

Leurs figures plus que les nôtres sont proches de la couleur de la terre.

Et nous voyions dans leurs mains les armes et les outils primitifs,

Et au milieu d'eux se tenaient les Rois et les Seigneurs, et au-dessus de leurs têtes oscillaient les vieilles idoles,

Les monstres à trois visages, accroupis, d'où sortent six paires de bras.

[...]

Et sur eux avec des mains de bourreau avaient établi leur domination avec sécurité

Brahma, Prince de l'Erreur, et Bouddha, le démon de la Paix.

The reference to «les monstres à trois visages,» appears to be an allusion to Trimurti (sanskrit "tri" = three, "murti" = divine form; embodiment), the triple manifestation of Ishvar (God), in the form of Brahma, the creator, Vishnu, the preserver, and Siva, the destroyer. In l'Evangile d'Isaïe, referring to the Holy (Christian) Trinity, Claudel comments: "Les Hindous ont cru la représenter, cette Trinité sous la forme de trois dieux identiques, amalgamés en un seul et qui se tournent le dos." However, the Hindu Trimurti is not, in fact, a representation of the Holy Trinity; the confusion stems from Claudel, as has been pointed out, in another context, by Jean Biès: «C'est Claudel qui fait l'erreur, en amalgamant 
Trimûrti et Trinité» (Biès, 168, note 234). Furthermore, the mention of Brahma and Buddha leaves no doubt as to the Hindu/Buddhist identity of the enemy Tête d'Or is battling.

\section{Le Repos du septième jour}

Le Repos du septième jour, Claudel's play about a descent into Hell, was written in 1896, when Claudel was posted in China. The playwright describes it as, "un drame d'étude, à la fois un moyen pour moi d'explorer ce que je commençais à comprendre ou à apprendre de la Chine, et d'autre part un moyen de sonder et de me faire une idée sur certains problèmes théologiques qui se posaient également à mon esprit.» Scholars such as Hue and Gadoffre have extensively discussed the Chinese sources and themes of this play. However, as Hue concludes, Le Repos du septième jour, " [... .] doit beaucoup plus à l'Inde qu'à la Chine.» The central action, that of the Emperor's descent into Hell, appears indeed, to be based on the well known Indian legend of Maudgalyayana, a disciple of the Buddha, who descends into Hell in order to deliver his mother, relegated there to expiate a sin (eating meat) she did not knowingly commit.

Although Claudel does not state anywhere, that the theme of $L e$ Repos du septième jour is borrowed from Indian legend, there are unmistakable parallels between his play and the legend. In both, there is, to begin with, a sin - one that the alleged sinner is unaware (s)he has committed. A living person agrees to descend into Hell in order to rescue and deliver the tormented soul(s). According to the legend, Maudgalyayana offers to take his mother's place in Hell; in the play, the Emperor sacrifices himself in order to save his people. And though Maudgalyayana undertakes the dantesque journey out of filial devotion, to save his own mother, whereas the Emperor in Claudel's play seeks to preserve all his subjects from being haunted and harassed by the dead, the first person that the Emperor encounters, upon arriving in Hell, is his mother.

The theological issue in both the legend and the play is the question of redemption. In the Indian legend, the Buddha himself appears before Maudgalyayana, and reveals how the latter's mother may be delivered: by performing a ritual ceremony for the dead, in the seventh month of the calendar, a month when the earth enters its period of rest. In Le Repos du septième jour, Claudel opts for a more judaeo-christian tradition, explained in the play by the Emperor: 
Six jours que l'homme travaille, [...]

Mais que le septième jour ne le trouve pas occupé à ce labeur servile :

Qu'il lave son corps et qu'il mette un vêtement nouveau, Et qu'il se tienne debout sur la terre, comme un prêtre auprès de la table des offrandes.

Thus, although the origin of the celebration in the play's title may perhaps be an Eastern, Buddhist legend, the mythological source of an important religious ceremony of India and other Buddhist nations, in Claudel's rewriting, Western tradition finds representation.

Furthermore, this play, whose source appears rooted in Buddhist theology, is the locus for the expression of one of Claudel's particularly strong criticisms of Buddhism. The anti-Buddhist lesson is recited at length to the Emperor by the Demon, «le Précepteur infernal,» who actually appears to be none other than Lucifer, for he introduces himself in the following terms: "A la face de Dieu j'ai dit Non! Au jour du schisme, retournant mon coeur sur lui-même, j’ai refusé l'aveu!"

In long verses of Biblically inspired poetry, Lucifer discourses upon the mysteries of Hell - death, suffering, punishment, etc., and impresses upon the Emperor that Buddhism is «la Connaissance invertie, la Fin retournée sur la cause.» To make sure that the Emperor has learned his catechism well, and will in turn be able to teach the lesson learned in Hell to his subjects, he is then interrogated by "I'Ange de l'Empire:"

L'ANGE DE L'EMPIRE: Je t'interrogerai et j'éprouverai ta doctrine.

Que dis-tu qu'est la peine que l'on applique ici?

L'EMPEREUR: Elle est triple selon son triple sujet :

L'Ignorance, l'Antiforce, l'Antiscience.

L'ANGE: Pourquoi ce mot anti et quel est le principe de cette peine?

L'EMPEREUR: La fin retournée sur la cause.

L'ANGE: Tu as bien répondu.

The Emperor thus undergoes a process of evangelization, and when the lesson is complete, he returns to earth. At the play's beginning we are not 
told the name of the Emperor, nor do we know over what kingdom he rules. However, on the basis of some of the titles that he bears, such as «Tenant-le-sceptre-de-jade,» «Revêtu-de-vêtements-jaunes,» etc., we can surmise that he is not a Christian king, and that he reigns over an Oriental kingdom. That we are dealing here with a Buddhist kingdom, is later apparent, for in the course of a dialogue between the Emperor and his mother, she refers explicitly to "vos temples sur la terre,» and to «Bouddha (qui) sourit au milieu d'eux.»

When the Emperor is about to begin his descent, he requests that the Imperial Staff be brought to him: "O Bâton, coupé dans la sainte contrée de l'Ouest! / Le père de ma race, s'appuyant sur toi, entra dans ce pays et s'établit au-dessus du peuple." When he returns from his ordeal in Hell, the staff has miraculously been transformed into a Cross:

\section{L'EMPEREUR, levant le bâton impérial qui maintenant a la} forme d'une croix. - Voici le bois royal!

O mes ancêtres, ô mon fils, ô mon peuple!

Je ne vous ai point dérobés! Comme l'antique Exilé l'ayant repris dans ma main,

De la profondeur de la terre je rapporte le baton d'investigation et de commandement, cela sur quoi l'Empereur s'appuie, La mesure du monde, l'étalon de sagesse et de puissance! Regarde!

LE PRINCE HERITIER. - La prophétie est accomplie. La tige a poussé des branches.

[...]

Nous te saluons, Crucifère!

The Emperor, who was earlier referred to as «Tenant-le sceptre-de-jade, etc.,» now describes himself as «le Pasteur des hommes.» «Je possède la Sagesse,» declares the Emperor, "Et ce n'est point Bouddha qui dort, ni le Tao pareil au dragon dans la nue, ni le tourbillon du Yang avec le Yin, ni l'inextricable enchevêtrement des hiérogrammes." Oriental philosophies and religion have been discarded, the conversion seems to be complete.

Claudel, however, takes this process of conversion yet a step further. Not content with comparing Christianity with the religions of the East, and dismissing the latter in favour of the former, the playwright effects another kind of conversion, a reduction to nonsense of the language of the Other. This second conversion takes place just before the 
Emperor's passage into Hell, in the scene in which the Nécromant is trying to raise the spirit of Hoang-Ti. The stage is dark, lit only by red candles stuck in the ground; in the semi-obscurity is a «carré magique;» and incense is burning. The Emperor signals to the Nécromant to begin:

LE NECROMANT, accroupi, à demi-voix: Om! a, a, i, i, u, u, ri, ri, li, li, e, ai, o, ou!

Om! ka, kha, ga, gha, na! (Il achève à voix basse et répète plusieurs fois la même formule.)

Se relevant, à voix haute :

Om! a, a, i, i, u, u, ri, ri, li, li, e, ai, o, ou, angah! çwahah!

What Claudel presents here seems to be a pagan ritual, some sort of black magic hocus-pocus. The crouching position of the Nécromant enhances the primitiveness of the scene; the adjective "accroupi» has always had a pejorative value in Claudel's register.5 Further, in all his writings, whether related to religion or not, Claudel has always sternly condemned any belief in superstition or magic. One such example of his disdain for magic is evident in his dismissal of Yoga, which he compares to «(les) ridicules pratiques de la magie.» There is a great deal of irony at play in this scene, all the more powerful because what may seem to Western readers a series of nonsensical sounds and syllables, "a, a, i, i," etc., is not nonsense at all, but the Sanskrit alphabet. These vowels, and the consonants uttered subsequently in the same scene, are the foundation of classical Sanskrit, the language that serves as vehicle for the entire Vedic corpus, comprising Hinduism's liturgical canon and exegetical texts, as well as the two great epics the Mahabharata and the Ramayana, the classical plays of Kalidasa, the Puranas, which are the repositories of Hindu lore, and the Tantras. Claudel renders this sacred language profane, and nonsensical, by employing it within the context of a black magic ritual.

The irony of this scene is heightened by the invocation «Om!» at the beginning of the series of vowels and consonants. The word, syllable, or sound, "Om," names and represents Brahman, the Absolute, and is the most sacred word of the Vedas. It is considered the primordial sound, having come from the throat of Brahma. Notes in Claudel's journal, and his use of the famous verse "Om Mane Padme Hum" in Conversations dans le Loir-et-Cher, leave no doubt that he was aware of the importance and centrality of this symbol to Hindu religious practice. And the irony of the pseudo-religious, magical incantation is further underlined by 
Claudel's ending it with the word «çwahah,» which is the sacred formula uttered during the offering of prayers and oblations to God.

A final, unquestionably pagan element is added to this black magic ceremony with the slaughter of a black chicken, and the sprinkling of its blood. Animal sacrifices are not generally common in Hinduism (though practiced by certain sects and cults), and one of the fundamental precepts of Buddhism is non-violence, and respect of all living beings.

Thus, by lumping together sacred and profane symbols, and religious and pagan rituals, Claudel subverts the first term of these pairs of opposites, and reduces to nonsense, the symbols, practices, and language of the Other.

This subversion, moreover, is deliberately undertaken. In case any reader mistake the incantation for what it appears, at first sight to be, namely, a meaningless, mystifying, chant, Claudel's Nécromant spells out what he is doing:

Je te conjure par la force des lettres,

Les voyelles que l'âme expulse du corps qui s'ouvre jusqu'au fond,

Les graves et les aiguës, l'a et l'i,

Et les consonnes par qui la bouche donne passage de ses trois portes, la langue, les lèvres et les dents!

Finally, Claudel adds parody to subversion. When the earth closes over the Emperor, and he finds himself in the thick darkness of Hell, his first words echo the Sanskrit vowels:

Ah ah! oh oh! où, où

Suis-je?

Absorbé,

Englouti, enfoncé!

Hell is where the language of the other is automatically spoken.

\section{Le Livre de Christophe Colomb}

In this, Claudel's last major dramatic work, the poet once again borrows an episode from classical Hindu mythology, refashioning it for his own 


\section{Claudel's Poetic Conversions}

evangelizing, ideological purposes. Le Livre de Christophe Colomb, written in 1927, dramatizes the vision of Christopher Columbus, and the trials and tribulations he had to undergo in order to attempt its realization. In Claudel's play, Columbus is more a missionary than an explorer, sailor, or merchant, burning with a desire to unite all the peoples of the earth under the banner of Catholicism. Thus he finds an ardent champion in Her Most Catholic Majesty, Queen Isabelle. The play opens with a solemn Processional, in which the Book recounting the life and voyages of Columbus is installed on the stage. This first, very brief scene sets the tone for the rest of the play:

L'EXPLICATEUR. - Le Livre de la Vie et des voyages de Christophe Colomb qui a découvert l'Amérique! $\mathrm{Au}$ Nom du Père et du Fils et du Saint-Esprit.

LE CHOEUR, d'une voix tonnante. - Ainsi soit-il!

The "Explicateur" is the narrator who recounts what transpires between scenes. Both part of, and external to the play's action, he sometimes performs the functions of describing decor, and providing stage directions. He also directs and keeps the Choir in order, and together with the Choir, represents the voice of posterity and the judgement of men vis à vis Columbus. In the second scene, which is a prayer, the Explicateur continues:

Car c'est lui qui a réuni la Terre Catholique et en a fait un seul globe au-dessous de la Croix. Je dis la vie de cet home prédestiné dont le nom signifie Colombe et Porte-Christ, telle que cela c'est passé non pas seulement dans le temps, mais dans l'Eternité. Car ce n'est pas lui seulement, ce sont tous les hommes, qui ont la vocation de l'Autre Monde et de cette rive ultérieure que plaise à la Grâce Divine de nous faire atteindre. LE CHOEUR, de même. - Ainsi soit-il!

Much is made throughout the play, of the fact that the explorer has such a seemingly pre-ordained name, - the Dove that bears Christ - to the New World. Doves appear in several scenes of the play; in a scene entitled «Irruption des Colombes» the playwright calls for a whole host of white doves to be released and to engulf the stage. 
The scene with elements borrowed from Hindu mythology occurs towards the end of the first half of the play. Columbus has succeeded in finding support and resources for his mission, recruitment of sailors has been completed, the three ships have been commissioned and are about to embark. The playwright turns his attention to what is going on, meanwhile, in America, «à l'heure où va finir pour elle cette longue nuit antérieure à la naissance et où le premier rayon de soleil va la toucher et la restituer à l'Humanité.» The scene is entitled «Les Dieux barattent la mer.»

The Churning of the Ocean is an episode from Indian mythology, recounted in both Hindu epics, the Ramayana (i. 45), and the Mahabharata (i. 17). Briefly, the myth runs as follows: When the world was young, neither the gods, nor their half-brothers, the demons, were immortal. Resolved to conquer their mortality, they held a conference presided over by their grandfather Brahma, and came to the conclusion that if they churned the Sea of Milk (the sixth of the seven oceans, which, in ever-widening circles lie beyond our world), they would obtain amrita, the elixir of immortality. The great Naga (snake) Ananta, a manifestation of Vishnu, uprooted the Mandara mountain, which served as a churning pole. The mountain was placed in position in the middle of the Sea, and another Naga, Vasuki, agreed to serve as churning cord. The gods took hold of his tail, the demons of his head, and for more than a thousand years, they pulled the serpent backward and forward, until the sea of Milk began to yield its treasures. Several divine gifts and deities emerged from the frothy waters, including Surabhi, the cow of plenty, nourisher of all living beings, Lakshmi, the consort of Lord Vishnu, priceless jewels, the Apsaras, or heavenly nymphs, and so on. The last to emerge, bearing a cup of amrita, was Dhanawantari, the physician of the gods, and the founder of the Ayurvedic system of medicine. Although it had been agreed that gods and demons would share equally in the product of their toil, once the elixir was obtained, the agreement was forgotten. A great battle ensued, raging for many days, during the course of which the demons were destroyed. The gods drank the amrita, passing the cup from one to the other, and obtaining, as they did so, the gift of immortal life. Greatly delighted by their success, they put Mount Mandara back in its place, and returned to Heaven where elaborate arrangements were made for the elixir's safe keeping. A great wheel, razor-sharp, and as brilliant as the sun, revolves around it ceaselessly, and two immense serpents with winkless eyes, keep watch night and day. 


\section{Claudel's Poetic Conversions}

Claudel's version of the churning of the ocean takes place on the shores of America. The earth is trembling, pagan temples and idols are crashing down, and the scene depicts all the gods in a frenzied panic, running helter skelter, afraid of what will befall them once Columbus and Christianity disembark on their so far uncontested territory. Some of the gods are reported to be engaged in acts of sabotage, frying up mountains of snow to create immense barriers of fog on the ocean, falsifying Columbus's compass, spoiling the crew's provisions by turning the wine, putting roaches in the flour, and worms in the salted beef, and even practicing viral warfare by using syringes to infect the sailors with «la fièvre, l'ennui, la folie et le désespoir!»

These frightened gods are mentioned by name; they include Huitchlipochtli, Quetzalcoatl, Tlaloc, Ixtlipetzloc, Panchacamac, and Hikchtli-Horktchli. «J'ai peur! j'ai froid! j'ai chaud! je claque des dents,» complains Tlaloc. «J'ai la colique! j'ai une espèce de ver dans les boyaux qui me fait beaucoup de mal! laments Ixtlipetzloc. «Hélas! hélas!» wails Huitchtlipochtli, «c'est fini de mes grands repas de chair humaine! [. . .] Ce coeur pantelant que le prêtre debout sur une montagne de cadavres retirait des entrailles de sa victime, que c'était bon!» Thus, it appears that we are dealing here with «Native American» Indian gods, and one may well ask how the oriental, specifically Hindu myth is connected to their dismay at the impending end of their reigns.

The answer lies in the person of the "Appariteur," who summons all the gods together and explains that he has thought of a scheme to sabotage Columbus's voyage. This is to be achieved by churning the ocean, by agitating it to such an extent that Columbus's three puny ships would not survive. "Vous y êtes?» asks the Appariteur of all the assembled gods; "rappelez-vous le temps où avec le serpent Naga comme ribot nous barattions ensemble la mer de lait!»

This scene calls for several comments. To begin with, the myth of the Churning of the Ocean of Milk is extracted from its original, Hindu repository, and reclassified by Claudel, as belonging to the collective memory, not only of the Aztec gods mentioned by name, but also of all the gods of every possible, non-Christian mythology. All these are summoned by the Appariteur:

Arrivez ici, arrivez ici! vous tous, tous les dieux, vous les dieux du Nord et du Sud! les dieux de la racine et de la feuille! les dieux de la cendre et de la bouillie! les dieux du salpêtre et du cuivre! les 
dieux de la fièvre et de la faim! boraciques et ammoniacaux! les camarades à becs de perroquets et de tapir! les chauffeurs de volcans! Les hocheurs de Cordilères! et vous qui à la queue du Scorpion aiguillonnez jusqu'à la frénésie la danse monstrueuse de l'Antarctique!

Analysis of this particular example of orientalism, that is, of the borrowing and rewriting of a Hindu legend, demonstrates the deep schism between Self and the Other in Claudel. Catholicism of the Self is opposed to its absence in the Other, to such an extent, that all Others merge into one; Hindu or American Indian, Nordic or Antarctic, all differences are erased due to the one common characteristic all these religions, mythologies, and cults have in common, namely, their non-Catholicity. The notion of universality that the etymology of the term "Catholic" supposes, is expressed most literally, yet at the same time, in a most paradoxical way by Claudel. The particular is simply not allowed to be, - or, several particulars melt into a rival, or parallel universal.

Further, as rewritten by Claudel, the entire scene appears as a satirization of the original Hindu myth. The Appariteur - a strange title given by Claudel to the character who only appears in this single scene plays here a role akin to Brahma's. While the title «Appariteur,» brings to mind «apparition», or evokes the role of the «opérateur» in Mallarmé's project of the supreme Book, the term is, strictly speaking, not a theatrical one. «Appariteur» is a specialized term borrowed from the field of academics, and is defined as a «huissier de faculté.» According to the literal meaning of the term, an appariteur is supposed to be at the service of, and subordinate to, the body he is attached to (the faculty of a university). However, in Le Livre de Christophe Colomb, he does not serve the gods; on the contrary, he is the figure of authority. Like Brahma, he devises the scheme and oversees its execution. Yet, he is not the benevolent, indulgent grandfather that Brahma is; instead he is a tyrannical overlord, a virtual slave driver, instructing the devils at his service to punish those not pulling their weight. The churning scene in Christophe Colomb is in fact choreographed to mimic the working of a slave chain gang:

L'APPARITEUR. - Attention! de l'ensemble! du muscle et de l'ensemble! Hhé-hhan! hhé-hhan! Ça va! ça va! plus fort! Tous ensemble!

TOUS LES DIEUX. - Hhé-hhan! hhé-hhan! hhé-hhan! hhé-hhan! 


\section{Claudel's Poetic Conversions}

Ils tirent et lâchent, ça marche avec une énergie formidable. Il y a devant eux un démon qui tape sur un gong pour donner le mouvement. Des petits diablotins courent tout le long des rangées pour rafraîchir les travailleurs avec des éventails. D'autres tapent en mesure à grands coups de bâton sur les paresseux.

L'APPARITEUR. - Tape dessus! tape dessus! mords-les! travaille-leur l'échine!

The tyranny of the Appariteur recalls Claudel's description of Brahma (in Tête d'Or), as someone who dominates his people «avec des mains de bourreau.» In addition, the feverish activity of the churning scene in Claudel's play generates an infernal din, «un bruit monstrueux de râpe et de scie.» Punctuated, not with praying, but with braying («hhé-hhan, hhé-hhan") this is a far cry from the celestial music that is normally supposed to accompany the pursuits of the gods.

The scene, as stated above, is entitled «Les dieux barattent la mer.» However, in the very first stage direction, the gods are stripped of any divinity they may have possessed, and are immediately, with no transition, referred to as demons: "Sur la plage décorée de constructions fantastiques et à moitié écroulées, tous les démons de l'Amérique costumés à la manière des idoles mexicaines se sont réunis." All the gods of the world, from North, South, or East, are represented as terrified and powerless, reduced to fabricating petty schemes of sabotage in the face of this one Western mortal, sailing toward them. And whereas in the original Hindu myth, the churning of the ocean yielded the desired outcome, namely, the elixir of immortality, in Claudel's retelling, the conclusion is foregone. Although the ocean has been churned to the maximum, although the Appariteur declaims: "La mer bout depuis l'Amazone jusqu'au Cap des Tempêtes! Quel saladier! quel soupe au lait! Nous allons voir ce que Monsieur Christophe Colomb va faire là dedans avec ses petites caravelles!" the collective endeavor of all the non-Christian forces of the world is doomed to failure. Christopher Columbus arrives in America, to evangelize it, and to put an end to its long age of darkness.

The examples considered above reveal the manner in which Claudel borrows material from Oriental sources, and poetically refashions it to meet his own ideological ends. Sublime and exquisite poetry effect the refashioning, rendering its subversive character barely perceptible. This point may be further illuminated by contrasting Claudel's 
orientalist poetic strategy in the examples analyzed above, with the example of L'Endormie, a short, one-act play which may perhaps be the first dramatic piece Claudel ever wrote.

\section{L'Endormie}

In contrast to Tête d'Or, Le Repos du septième jour, and Le Livre de Christophe Colomb, L'Endormie appears to be a play in which the borrowed Oriental material remains pure and unmediated. Written before Claudel's formal entry into the Catholic church, L'Endormie seems to be an Eastern theme transposed into the purest poetic theater.

E. Roberto in L'Endormie de Paul Claudel ou la naissance du génie, has attempted to trace all the sources that have influenced Claudel in the writing of this, his first play. Among those listed are Mallarmé, Rimbaud, Monet, Debussy, Hugo, Baudelaire, Leconte de Lisle, Shakespeare, Keats, Maeterlinck, Theocritus, Virgil, Aristophanes, Homer, Euripides, and many others! Even if Claudel really had to draw on all these sources to write a short single-act play, it is also possible to read Claudel's play, abstracted from all Western literary sources, as the transposition into theater of the Hindu concept of Maya, the eternal, universal illusion. We may recall that $L^{\prime} E n d o r m i e$ was written at a time when Claudel was a student of philosophy, and that his teacher was Burdeau, a fanatical Schopenhauerian, indeed, the foremost translator and popularizer of Schopenhauer's work in France.

According to Schopenhauer, the world of appearances is an illusion, represented in Hinduism by the concept of Maya. The «éternelle endormie» of Claudel's play, Galaxaure, can be viewed as a symbol of this illusory world. Taken in by the veil in which Maya cloaks the essence of the universe, the Poet in L'Endormie is deceived by his senses, first mistaking the old and ugly Strombo for the most beautiful woman in the forest, then being tricked again in the cave, where he discovers a monster instead of the nymph he believed he was pursuing: "Oh! quand je suis entré, son ventre était balayé par les rayons de la lune, je le prenais pour le sein d'une géante." Lingering echoes of the lesson learned by the poet in L'Endormie, "Oh! dire qu'il n'y a rien de vrai dans tout cela!" will appear later in La Ville in the form of Isidore de Besme's repeated murmurs: «Rien n'est!» 


\section{Claudel's Poetic Conversions}

The predicament of the Poet in $L^{\prime}$ Endormie is similar to the predicament of the God Siva in Indian mythology. Recounted in the ancient Hindu and Buddhist texts, the Ramayana and the Lalita Vistara, the "Enchantment of Siva" is perhaps one of the most famous legends illustrating the theme of Maya. Jealous of Siva's omnipotence, the lesser gods order an Apsara to enrapture Siva in the thralls of an illusory love, and lead him to his death. Siva resists, to begin with, then succumbs to the lure, and pursues the nymph through the forest. When, after a harrowing chase through the night, he finally catches her, and embraces her just as day is breaking, the veil of Maya drops, and Siva is left holding a monstrous creature in his arms.

The poet in $L^{\prime} E n d o r m i e$ is, similarly, a victim of the confusion between dream and reality. He believes he has glimpsed Galaxaure, « la blanche, la plus belle des nymphes, " when he actually was pursuing the hideous Strombo. And so taken up is he by the object of his dreams, that he refuses the attentions of the beautiful Volpilla, who is very real, in love with him, and ready to give herself to him.

Although L'Endormie was written even before Claudel wrote Tête d'Or, it was not published until 1925. By this time, Claudel's metaphysical concepts had undergone a sea change, and the idea that Nature could be no more than an illusion was tantamount to blasphemy. « La Nature n'est pas illusion, mais allusion, » he was to write in his Journal, and this is the defining character of Nature as it appears in his later works.

\section{Notes}

1 This point is underlined by Jean Biès, who comments: "A voir tant de mépris (de l'Autre) et une telle sûreté de soi, l'on se pose la question : L'un de nos plus grands poètes chrétiens, et peut-être le plus grand, était-il vraiment Chrétien?" Biès, Jean. Littérature française et pensée hindoue. N.p.: Librairie C. Klincksieck, 1974.

2 Said, Edward W. Orientalism. New York: Vintage Books, 1978.

3 Claudel, Paul. Mémoires Improvisés. Paris: Gallimard, 1969. 126.

4 B. Knapp suggests that a possible source for the name Agnel is «Agni, the Vedic fire God, a metaphor most suitable to Claudel's solar hero.» Knapp, Bettina. Paul Claudel. New York: Frederick Ungar Publishing Co., 1982, 38.

5 Cf. the description, above, of the pagan army in Tête d'Or, carrying idols of «les monstres à trois visages, accroupis, d'où sortent six paires de bras.» 